\title{
EWA RAJEWSKA
}

iD https://orcid.org/0000-0002-8561-0638

Uniwersytet im. Adama Mickiewicza w Poznaniu rajewska@amu.edu.pl

\section{KRYTYKA PRZEKŁADU I OKOLICE}

Krytyka przekładu nigdy nie znajdowała się w samym centrum badań przekładoznawczych. Na mapie Jamesa Holmesa, czytanej od lewej, zajmuje ostatnią pozycję, skrajną prawą, ujętą w punkcie 3.24 jako „Translation Criticism” (Holmes 1972: 78; Toury 1995: 10). „Ostateczna poważna przeszkoda [one final great stumbling block] na drodze każdego, kto interesuje się przekładoznawstwem", napisała o niej we wstępie do Translation Studies Susan Bassnett (2013 (1980): 19). A to przede wszystkim ze względu na brak uniwersalnego modelu, w odniesieniu do którego można by oceniać przełożone teksty. Kryteria wartościowania są przecież uwarunkowane historycznie i kulturowo, a przekład - każdorazowo ściśle związany z kontekstem, w którym powstał (Bassnett 2013: 20). Carol Maier, autorka hasła „Reviewing and Criticism" w Routledge Encyclopedia of Translation Studies, przypomina ponadto, że przekładoznawstwo nigdy takiego uniwersalnego modelu nie miało, a współczesny dyskurs o przekładzie, eksponujący wielowariantywność translacji, różnicę oraz widoczność tłumacza/tłumaczki i jego/jej decyzji przekładowych, wręcz ich „drugoautorskość”, każe wątpić, czy taki model jest w ogóle możliwy - a nawet potrzebny (Maier 2009: 236, 241).

Do braku uniwersalnych narzędzi, pozwalających nam kategorycznie zdecydować, co jest w każdych warunkach przekładem „dobrym”, a co „złym”, dochodzi jeszcze kwestia odpowiednich kompetencji: językowych, literackich, kulturowych. Czasu, cierpliwości i akrybii. Na polskim gruncie Edward Balcerzan pisał o sporadycznym, „znikliwym” istnieniu krytyki przekładu, która obliguje badaczy do podwójnej, „konfrontacyjnej” lektury, zestawiającej przekład z oryginałem. W dodatku procedura ta nie powinna się 
odbywać bez pamięci o przekładach innych, konkurencyjnych, tworzących serię przekładową danego obcojęzycznego tekstu (Balcerzan 2009: 133). Krytyka przekładu to dziedzina wymagająca, metakrytyka - tym bardziej.

Nic więc dziwnego, że ostatnie lata przynoszą stosunkowo niewiele publikacji choćby w części poświęconych krytyce przekładu jako subdyscyplinie, jej zadaniom i perspektywom. A jednak temat wraca - w ujęciu stosowanym, nie teoretycznym. Praktyka nie znosi próżni. O tym, co jest przekładem „dobrym”, a co „złym”, decydujemy doraźnie. Kolejną wersję swojego modelu oceny przekładu opublikowała Juliane House. „Wedle mojej wiedzy jest to obecnie jedyny w pełni dopracowany, wywiedziony z praktyki, przemyślany teoretycznie i zaprojektowany interdyscyplinarnie model ewaluacji jakości przekładu”, twierdzi badaczka (House 2015: 1). Autorską metodę analizy punktów krytycznych do oceny przekładów pisemnych zaproponowała Joanna Dybiec-Gajer (2013); krytyce przekładu może służyć także przejęta z egzegezy biblijnej i zaaplikowana do przekładoznawstwa przez Agatę Brajerską-Mazur metoda kateny (2012). Systemowi oceniania sporo miejsca w swojej metodologicznej książce poświęciła Maria Piotrowska (2007 i 2016).

Krytyka przekładu od dawien dawna znajduje się bowiem w samym centrum refleksji przekładoznawczej, a od zawsze - refleksji translatorskiej: czy myśl o fortunności lub niefortunności planowanego rozwiązania nie podściela każdej decyzji tłumaczki i tłumacza? Abstrahując od autokrytyki czy krytyki ksobnej, temperatura krytyczna translatorskich polemik bywa bardzo wysoka, a samo dokonanie tłumaczenia dzieła już przełożonego na dany język przez kogoś innego również mieści się per se w dziedzinie krytyki przekładu.

Nic więc dziwnego, że ostatnie lata przynoszą wiele niezwykle ciekawych publikacji krytycznoprzekładowych. By ograniczyć się do samych książek i wymienić przynajmniej kilka: stanowiącą wybór esejów opublikowanych w „Literaturze na Świecie” w latach 1984-2014 antologię O nich tutaj pod redakcją Piotra Sommera (2015), Gościnność słowa (2012) i Ttumacza między innymi (2018) Jerzego Jarniewicza, Powtórzenie i różnicę Tomasza Swobody (2014). Komentując wybór tekstów do tej pierwszej, Piotr Sommer wskazuje, co znamienne, na ich ateoretyczność i nienaukowość: „Są to szkice umysłowo najbardziej dziarskie i najbardziej niepodatne na żargony teorii, myślane i pisane «blisko» tekstu, pisane rzetelnie i fachowo, ale bez pretensji do naukowości, sprawiedliwe, ale niepodległe fantazmatom obiektywizmu" (2015: 6). 
Ta peryferyjność, a zarazem centralność - znikomość konstatacji z poziomu meta- przy akcencie położonym na wymiar praktyczny - krytyki przekładu w obrębie myśli przekładoznawczej bierze się zapewne z podwójności celu, jaki przed nią stoi. Są nim, jak twierdzi Edward Balcerzan, aktywność aksjologiczna oraz „odpominanie” obcojęzyczności oryginału. Pierwsza, zdawałoby się, wynika z drugiego. Drugie natomiast polega na tym, że

odmienność od oryginału stanowi konstytutywną cechę przekładu «jako takiego», a celem krytyki jest utrzymanie tego faktu w świadomości czytelnika. Podstawowym dążeniem krytyki translatorskiej pozostaje więc [...] ostrzeżenie lekturowe: znak inności, który ma przeciwdziałać naiwnemu zaufaniu wobec decyzji thumacza (Balcerzan 2009: 133-134).

W takim razie aksjologia bynajmniej nie jest najważniejsza? Pytanie o „dobry” lub „zły” przekład wcale nie jest głównym pytaniem krytyki przekładu?

Odróżnienie „zwykłej” recenzji (krytyki?) przekładu od przekładoznawczego studium nie sprawia większych trudności. Recenzja jest bardziej sprawozdawcza, mniej specjalistyczna i nastawiona na ewaluację; praca naukowa poświęcona tłumaczeniu coraz częściej stara się ocenności unikać. Współczesny dyskurs przekładoznawczy skłania do pisania o przekładzie tak, by nie stosować określeń wartościujących, a pojęcia „wierności”, „rzetelności” czy choćby „,adekwatności” - ale także na przykład „kongenialności” bądź „arcydzielności” - thumaczenia, zdawałoby się, już do niego nie przystają.

Tomasz Swoboda w przywoływanej już książce Powtórzenie i różnica pisze:

Nie będę udawał, że w zamieszczonych tu szkicach od krytykowania pojmowanego wprost - czyli ganienia, wytykania, bywa, że obśmiewania - uciekam. Sądzę jednak, że owo krytykowanie jest właśnie analizą i interpretacją: nie tylko samego thumaczenia, ale wręcz statusu thumacza i przekładu jako takiego (2014: 6).

Fantazmat obiektywizmu, jak chciałby Piotr Sommer? Bo czy pozbawiony ocenności opis naprawdę jest możliwy? Łatwiej rzecz zadeklarować niż wykonać. W pracach przekładoznawczych Elżbiety Tabakowskiej sformułowań aksjologicznych prawie nie ma - w książce Myśl językoznawcza z myśla o przektadzie poszczególne rozwiązania translatorskie zostały przez badaczkę ocenione dosłownie raz jako „,pomysłowo przełożone” albo 
„mniej fortunne” (2015: 55). Tomasz Bilczewski w swej znakomitej analizie „Sailing to Byzantium”, oświetlając Yeatsowski oryginał przekładami Czesława Miłosza, Stanisława Barańczaka i Jolanty Kozak (oraz zamieszczając incydentalne uwagi na temat thumaczeń Ludmiły Marjańskiej i Bogdana Czaykowskiego), zdecydowanie unika wartościowania; badacz zastrzega, że jego celem ,nie było stworzenie wartościującej hierarchii tych propozycji, lecz wskazanie rozmaitych możliwości interpretacyjnych, jakie one otwierają" (2010: 286). A jednak zdarza mu się pochwalić wyjątkową trafność niektórych rozwiązań (na przykład w tłumaczeniu Barańczaka, 2010: 271, 278). Analizując wybrane dramaty Szekspira w polskich przekładach, Agnieszka Romanowska zaznacza, że interesuje ją to, ,jakiego Szekspira dali nam Iwaszkiewicz, Miłosz i Gałczyński, a nie to, czy thumacze ci przełożyli go wiernie czy swobodnie, pięknie czy koślawo, «dobrze» czy «źle»” (2017: 20). „Krytyka przekładu (rozumiana jako czytanie i interpretacja tekstu) ujęta w kategoriach przekładoznawstwa kulturowego nie zajmuje się [...] różnicami między tekstem przekładu i tekstem wyjściowym jako odstępstwami od litery oryginału, lecz bada je jako rezultat twórczej działalności tłumacza”, pisze. Ale i jej zdarzają się - niezwykle rzadko niepowściągnięte uwagi o genialnym oddaniu komizmu sytuacyjnego (2017: 228, w przypisie) czy kapitalnie przełożonym imieniu (2017: 280, również w przypisie). Szczerze mówiąc, napotykamy je z przyjemnością, łącząc się z autorką w poczuciu oczarowania przez tekst, nieuniknionym, jak twierdzi Rita Felski, nawet u najbardziej zdystansowanych badaczy (2016: 65 i nast.). Oceniać jest rzeczą ludzką.

Przekładoznawcze prace naukowe bez wątpienia spełniają Balcerzanowskie kryterium drugie: odpominają „obcość” oryginału. Zastanówmy się: czy to nie za mało? Nietrudno sobie wyobrazić ujęcie, w którym większość tekstów przekładoznawczych, także tych próbujących się zdystansować od aksjologii, to krytyka przekładu sensu largo. Na wzór literary criticism dziedziny, która przecież w żadnym razie do samej ewaluacji literatury się nie sprowadza, a której polskim odpowiednikiem są badania literackie, literaturoznawstwo. Zatem krytyka przekładu jako przekładoznawstwo w ogóle? Czy to nie zbyt duże uogólnienie?

Równie dobrze można powiedzieć, że skoro kryteria oceny są nierozerwalnie związane z kontekstem - macierzystym tekstu przetłumaczonego i empirycznym krytyka - a więc historycznie zmienne, sam trzon przekładoznawstwa stanowi historia przekładu. Jak zauważa Ewa Kraskowska, 
zwrot kulturowy przyniósł [...] zainteresowanie całą, by tak rzec, infrastrukturą zjawisk przekładowych - instytucjami oraz osobami uczestniczącymi i pośredniczącymi w komunikacji translatorskiej, usytuowanymi w konkretnej rzeczywistości historycznej, społecznej i politycznej - co znacznie zmieniło warsztat pracy krytyka przekładu. Metody filologiczne i ujęcia teoretyczne ustąpiły w nim miejsca kwerendom w różnego rodzaju archiwach, perspektywie socjologicznej i historiografii (2018: 60).

Czy jeśli położymy akcent na wymiar temporalny (nawet świeżo opublikowany tekst stanowi cegiełkę, z której już powstaje gmach historii literatury), krytyka przekładu stanie się historią przekładu?

A przecież i ze ,zwykłą” recenzją przekładu, najbardziej wyostrzonym gatunkiem krytycznoliterackim, rzecz nie jest taka prosta. „Ignorowanie faktu, że [...] dobre tłumaczenia mogą unieść - i unoszą - pewną liczbę błędów, to droga na skróty", pisał Peter Newmark, autor rozbudowanego konfrontacyjnego modelu krytyki przekładu (1988: 191). W takim razie ile błędów może unieść dobry - czy choćby adekwatny - przekład? Oraz kto decyduje o tym, co jest błędem?

I tu wracamy omalże do punktu wyjścia: a w ramach której z teorii przekładu powstaje, na jakim teoretycznym modelu przekładu się wspiera nasza krytycznoprzekładowa, ocenna konstrukcja? Jeszcze „hieronimiańskim", piętnującym wiecznie winnego thumacza za to, że nie jest w stanie odwzorować świętego tekstu w skali 1:1 (Bassnett, Lefevere 1998: 2-3)?

„Przekład wiersza poety X przez thumacza Y jest pełen fatalnych błędów [...Z] upełnym skandalem jest, że thumacz mówi o «ogrodzie dyszącym wonią macierzanki», czyli Thymus serphyllum, podczas gdy w oryginale stoi jak byk «maciejka» (Mathiola bicornis). Z drugiej strony, trzeba odnotować z uznaniem, że przekład się rymuje”. Tak wygląda typowa krytyka przekładu,

szydził przed trzema dekadami Stanisław Barańczak (1992: 35). O „filologicznej pracy porównawczej" piszemy w pracach krytycznoprzekładowych już znacznie rzadziej niż dawniej, ,co zresztą w wielu wypadkach podnosi czytelniczą atrakcyjność krytycznotranslatorskich artykułów i monografii”, zauważa Ewa Kraskowska (2018: 59). I co do tego zapewne bylibyśmy skłonni się zgodzić: krytyka przekładu nie może być zbiorem przekładowych „kwiatków”.

À propos kryteriów oceny: jak się Państwu podoba nasza okładka? Docenili Państwo jakość techniczną zdjęcia i fotograficzną precyzję odwzorowania oryginału (co prawda - pozajęzykowego oryginału)? Czy jednak 
przeważyły preferencje osobiste: zaintrygował lub odrzucił Państwa jej wyrazisty kolor? A może owszem, przykuła wzrok, ale jeśli chodzi o jej temat, upodobania gatunkowe mają Państwo inne?

Niniejszy numer to również swego rodzaju florilegium. Prezentujemy Państwu wybór prac poświęconych krytyce przekładu - na świecie i w Polsce. Od szerokiej teoretycznej perspektywy i hermeneutycznego modelu krytyki przekładu od Friedricha Schlegla po współczesność w ujęciu Piotra de Bończa Bukowskiego, przez diagnozę Olgi Szmidt, która przedstawia krytykę przekładu jako remedium na kryzys koncepcji literatury światowej, po stosowane, krytycznoprzekładowe, poświęcone powieści Ostepy nocy Djuny Barnes/Marcina Szustra case study Izabeli Sobczak. Krzysztof Majer opisuje krytycznoprzekładowy wymiar retranslacji oraz własne zmagania z prozą Hermana Melville'a; Arkadiusz Luboń - polską recepcję krytycznoprzekładową poezji H.P. Lovecrafta. Przedstawiamy też nowe horyzonty: Joanna Dybiec-Gajer pisze o fanowskiej krytyce przekładu, Kinga Rozwadowska - o krytyce przekładu w Internecie. Tamara Brzostowska-Tereszkiewicz czyta najnowszą translatologiczną książkę $Z$ historii i poetyki przekładu Jerzego Święcha; Anita Kłos relacjonuje swoją lekturę Prawie to samo. O doświadczeniu przekładu Umberta Eco w tłumaczeniu Jadwigi Miszalskiej i Moniki Surmy-Gawłowskiej; Agata Hołobut odwiedza Miasta w przekładzie: Skrzyżowania języka i pamięci Sherry Simon, przełożone przez kolektyw thumaczek pod redakcją naukową Magdy Heydel.

Zapraszamy do lektury.

\section{Bibliografia}

Balcerzan, Edward. 2009. Tajemnica istnienia (sporadycznego) krytyki przektadu, w: Ttumaczenie jako ,, wojna światów”. W kręgu translatologii i komparatystyki, Poznań: Wydawnictwo UAM, s. 126-139.

Barańczak, Stanisław. 1992. Mały, lecz maksymalistyczny manifest translatologiczny, albo: Ttumaczenie się z tego, że tlumaczy się wiersze również w celu wyttumaczenia innym tlumaczom, iż dla większości thumaczeń wierszy nie ma wytlumaczenia, w: S. Barańczak, Ocalone w tlumaczeniu. Szkice o warsztacie thumacza poezji z dodatkiem Małej antologii przekladów-problemów, Poznań: Wydawnictwo a5, s. 13-63.

Bassnett, Susan. 2013 (1980). Introduction. W: Translation Studies. 4th ed., LondonNew York: Routledge, s. 12-21. 
Bassnett, Susan, Lefevere, André. 1998. Where Are We in Translation Studies? w: S. Bassnett, A. Lefevere, Constructing Cultures. Essays on Literary Translation, Clevendon - Philadeplphia - Toronto - Sydney - Johannesburg: Multilingual Matters, s. 1-11.

Bilczewski, Tomasz. 2010. Itinerarium 2. Znoszony łachman ciała: ,, Sailing to Byzantium" W.B. Yeatsa, w: T. Bilczewski, Komparatystyka i interpretacja. Nowoczesne badania porównawcze wobec translatologii, Kraków: TAiWPN Universitas, s. 253-289.

Brajerska-Mazur, Agata. 2012. Filutka z filigranu paraduje w cudzym losie. Wisława Szymborska w anglojęzycznym przekładzie Stanisława Barańczaka i Clare Cavanagh, Wydawnictwo KUL, Lublin: Wydawnictwo KUL.

Dybiec-Gajer, Joanna. 2013. Zmierzyć przekład? Z metodologii oceniania $w$ dydaktyce przekładu pisemnego, Kraków: TAiWPN Universitas.

Felski, Rita. 2016. Literatura w użyciu, przeł. zespół tłumaczy ze specjalności przekładowej IFP UAM, Poznań: Wydawnictwo „Poznańskie Studia Polonistyczne”.

Holmes, James.1972. The Name And Nature Of Translation Studies, https://archive.org/ details/Holmes 1972TheNameAndNatureOfTranslationStudies [dostęp: 9 września 2021].

House, Juliane. 2015. Translation Quality Assessment. Past and Present, London - New York: Routledge.

Jarniewicz, Jerzy. 2012. Gościnność stowa. Szkice o przekładzie literackim, Kraków: Znak.

—. 2018. Ttumacz między innymi. Szkice o przekładach, językach i literaturze. Wrocław: Wydawnictwo Ossolineum.

Kraskowska, Ewa. 2018. Porównywanie jako metoda przekładu, „Tekstualia” 3(54), s. 53-63.

Maier, Carol. 2009. Reviewing and Criticism, w: M. Baker, G. Saldanha (red.), Routledge Encyclopedia of Translation Studies, 2nd ed., London - New York: Routledge, s. 236-241.

Newmark, Peter. 1988. Translation Criticism, w: P. Newmark, A Textbook on Translation, New York - London - Toronto - Sydney - Tokyo: Prentice Hall, s. 184-192.

Piotrowska, Maria. 2007. Proces decyzyjny tłumacza. Podstawy metodologii nauczania przekładu pisemnego, Kraków: Wydawnictwo Naukowe Akademii Pedagogicznej (2016: Wydawnictwo C.H. Beck).

Romanowska, Agnieszka. 2017. Za głosem tłumacza. Szekspir Iwaszkiewicza, Miłosza $i$ Gałczyńskiego, Kraków: Wydawnictwo Uniwersytetu Jagiellońskiego.

Sommer, Piotr. 2015. To jest wstęp, w: P. Sommer (red.), O nich tutaj (książka o języku i przekładzie), Kraków - Warszawa: Instytut Książki, s. 5-11.

Swoboda, Tomasz. 2014. „Słowo od thumacza”, w: T. Swoboda. Powtórzenie i różnica. Szkice z krytyki przekładu, Gdańsk: Wydawnictwo w Podwórku, s. 5-7.

Tabakowska, Elżbieta. 2015. Myśl językoznawcza z myśla o przekładzie. Wybór prac, red. P. de Bończa Bukowski, M. Heydel, Kraków: Wydawnictwo Uniwersytetu Jagiellońskiego.

Toury, Gideon. 1995. Descriptive Translation Studies and Beyond, Amsterdam: John Benjamins. 